\title{
ボリヴィニルアルコール瀻維の濕熱 延伸に關する研究
}

川上博・李升”基”。

（昭和20年 11 年 5 日受理）

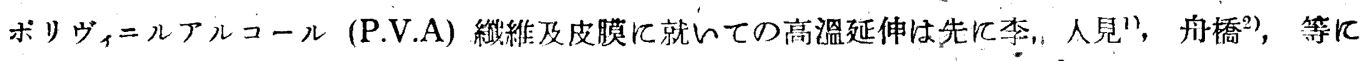
より研究され適當な溫庭で注意して延伸を行ふならば $90 \mathrm{~kg} / \mathrm{mm}^{2}$ ，之杰ふ侵秀な强茟を示す P.V.A

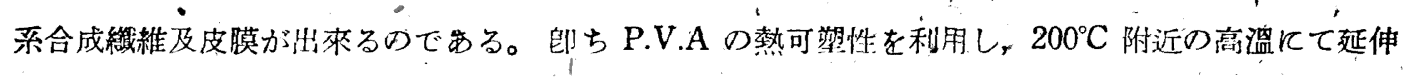
を行へば絲狀分可の配列が改善されその强度が止昇すると云子事賽が明白にされた。

高溫延伸，師乾熱延伂に關しては上述の如くであるが濕熱延伸の場命は如何に？，濕熱延伸とは水 て依名濕潤狀態で延伸を行ふ意罚であつて，ての場合水單獨に用ひたのでは P.V.A 繊維は溶解し延 伸は全く不可能であるが，紡䋺特て於けると同梯祭類溶液を使用すれば溶解してしまふ心配はないわ

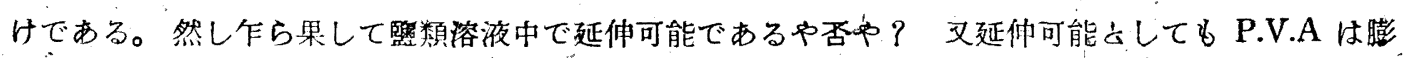

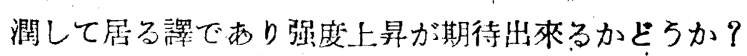

我々は之等の點を明らかにすべく實驗を行つたのであつて, 㬎熱延伸に 第 1 圆延伸燢置 より强度上昇の結果を得るならばてれを紡絲っ直結し，ょり簡單飞强力な る P.V.A 系合成㵶維が製造出來る之思はれるのである。濕熱延伸を行ふ

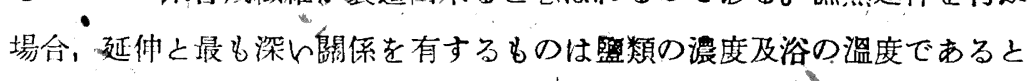
考へられるのであつて，我々は最初てての點を闌明した。そして大體延伸 出來ろ事が明瞭になつたので越伸率と强度との關係を確める可く實驗を行 つた。以下賽驗方法及整驗結果沉就々て述へる。

\section{堑驗並其の結果}

第I圖は裝置を示す。第 1 㵣几於て用ひた延伸器は $0.25 \mathrm{~mm}$ 迄测定可能 なものであり熱による膨脹は度外視した。

$\therefore$ 1) 種及の浴濃度及浴溫度に於ける延伸率

先づ最初基礎實驗を行つた。郎ち風乾 P.V.A 瀻維 $(2,11 \mathrm{~d}$. 强度 $3.39 \mathrm{~g} / \mathrm{d}$,

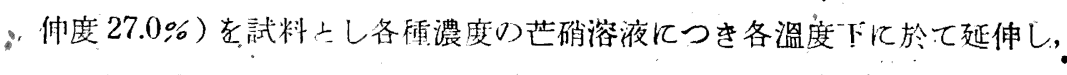
その切斷時に於ける延们萊を比較したのである。測定は原長 $10 \mathrm{~mm}$ 單維

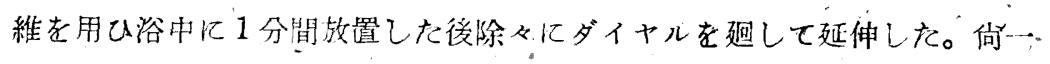

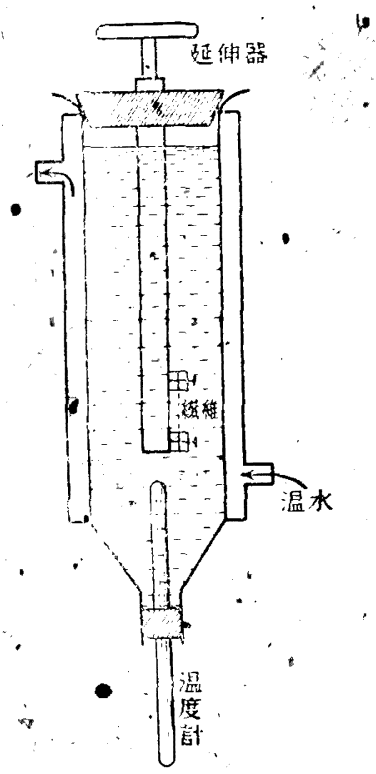
種䫏に就いて五回測定し結果はその平均值をもつてした。

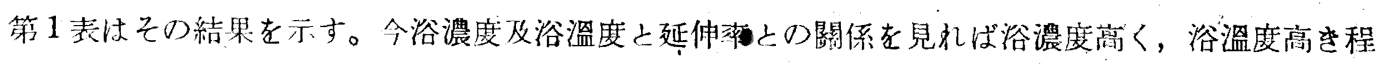

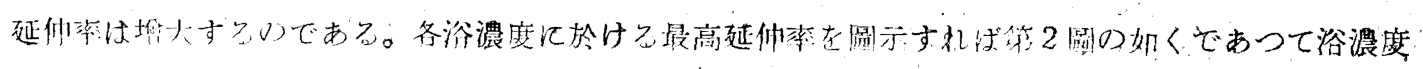




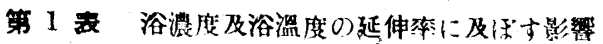

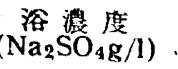

54

103

154

210

256

305

348

404

各浴溫度に於りる延伸率（\%)

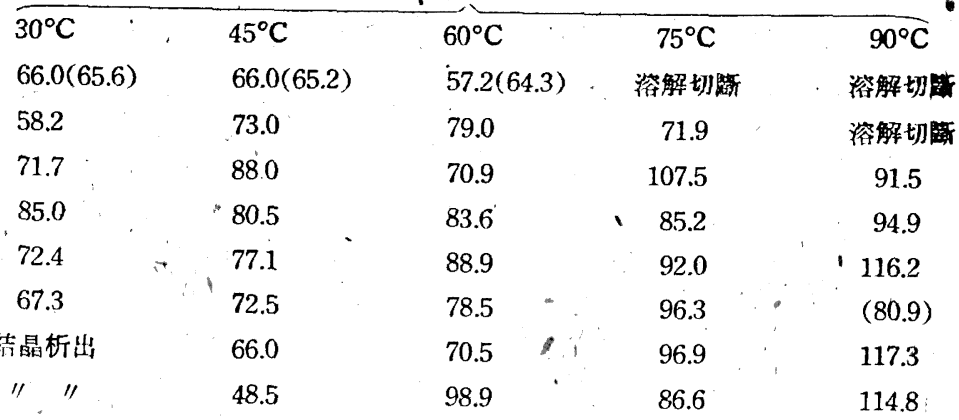

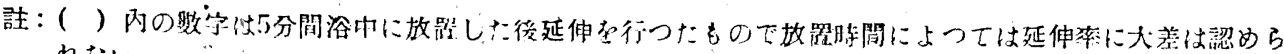
れない。

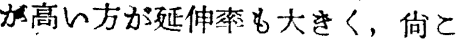

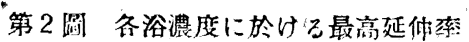

の場合最高延伸率范得子浴溫度 高くなつてるるのである。第 1 表, ‘ 第 2 圆の結果力ら浴浱度低き場合 は最高延伸率多低く，且最高延伸 率を得る溫度も低ん方が良んので あるが次第に浴摆度が上年するに つれ延伸率も堌大され溫度もより 高い方が好結果を示すのであつ て，之等の結果からすれ哚溫恠 は90 $90^{\circ}$, 沿漫度忙 $250 \mathrm{~g} / 1 \mathrm{Na}_{2} \mathrm{SO}_{4}$ 以上の方が延伸に好都会の樣に思 はれる。

以上一種類の纎維に就々て䁈驗 を行つたのであるが次に紡絲時の

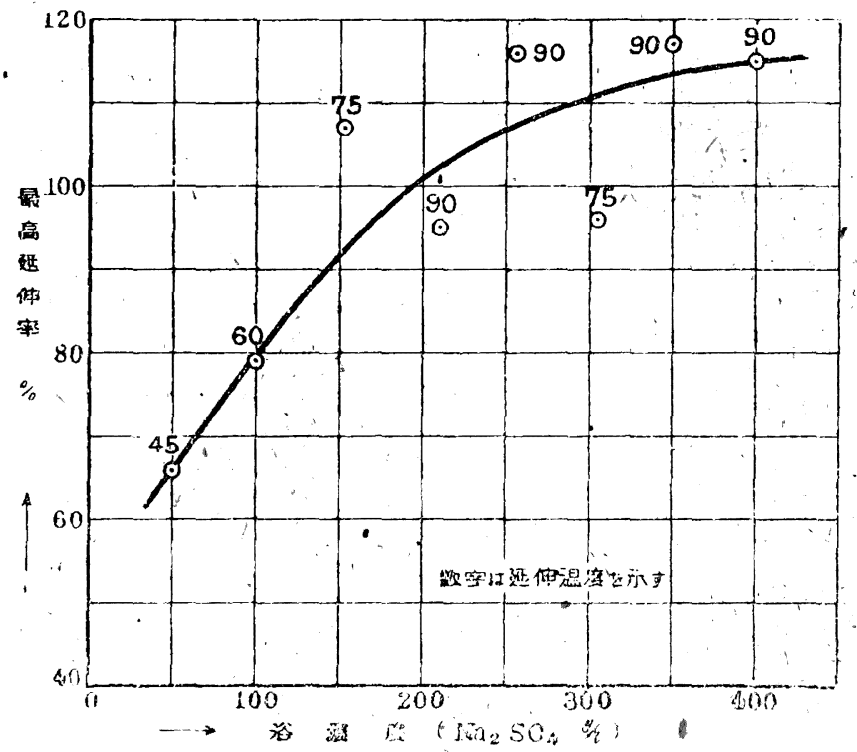

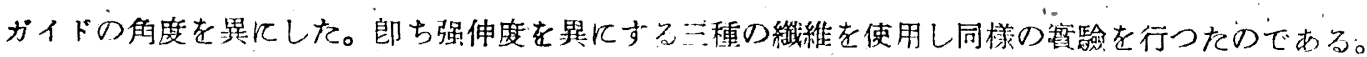

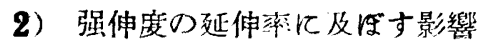

試料としては次のものを使用し前上同梯單維維に就んて五回測定してその4均値を採用した。 試 料 No.

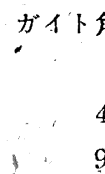

\section{0}

45

90

$テ^{*}=-n$
1.30
1.22
1.34

乾 强 (g/d)

乾 伸 (\%)

2.60
3.54
3.77




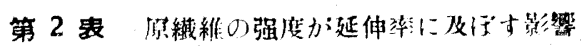

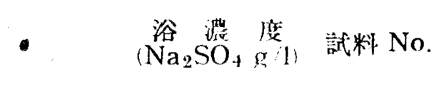
$103\left\{\begin{array}{l}a \\ b \\ c\end{array}\right.$
$205\left\{\begin{array}{l}a \\ b \\ c \\ 300\end{array}\right.$
$392\left\{\begin{array}{l}a \\ b \\ c \\ a \\ b \\ c\end{array}\right.$

第2表はその結果であり，第3㻁 は浴濃度之最高延伸菅の關係を圖 示したものである。第 2 表に於て は第 1 裴の如く餘り明膫な結果は 出なかつたのであるが, 先づ原緎 維の强度之延伸揫との關係をみる に强度が大きい程延伸は困難であ る。との事虽度弱く仲度大なる 原維維を用ひる方がより延伸され 一易結果を示すものである。次化 浴濃度, 浴溫度の關傜であるが, 大䯣第 1 表の結果と同㥞な倾向を 示してみるのであつて第 3 滑に見 る如くその最高延伸茶は浴濃度及 浴溫度の上昇に隨ひ增太してるる。

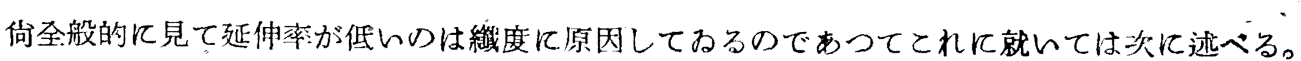

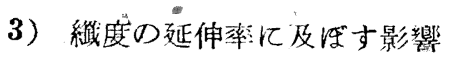

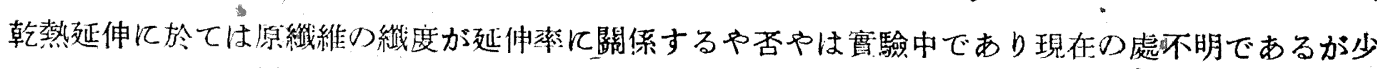

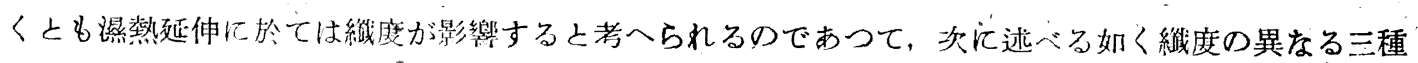
の原繊維を用ひ姃伸算驗を行つた。使用した浴は $\mathrm{Na}_{2} \mathrm{SO}_{4} 391 \mathrm{~g} / 1, \mathrm{ZnSO}_{4} 17 \mathrm{~g} / 1$ であり浴溫 $90^{\circ} \mathrm{C}$

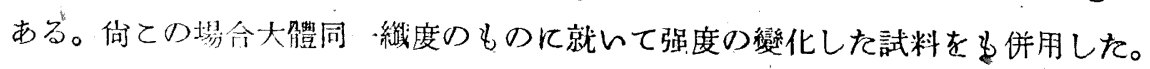

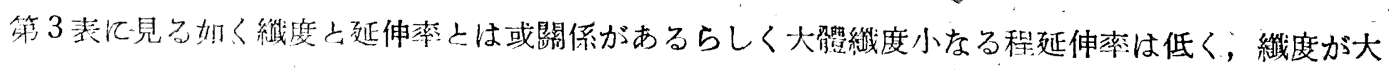

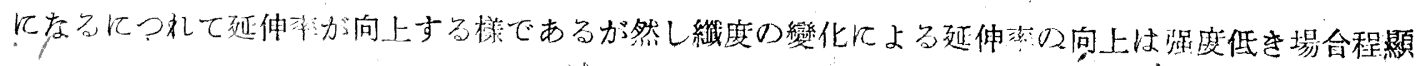




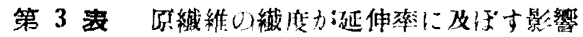

\begin{tabular}{|c|c|c|c|c|c|c|c|c|c|}
\hline 䋐，度 & 乾㬎(g/1) & 乾伸 $(\%)$ & 滋熱延伸呟 & & \multicolumn{3}{|c|}{ 乾鵁延伸菜（\%) } & \multicolumn{2}{|c|}{ 乾熱延伸保件 } \\
\hline 0.99 & 1.77 & 31.4 & 102 & & & 191 & . & $185^{\circ} \mathrm{C}$ & 倚㿿 $0.62 \mathrm{~g} /$ 本 \\
\hline 1.64 . & 1.67 & 38.9 & $\cdots 120$ & 2 & & 210 & & $190^{\circ} \mathrm{C}$ & "I \\
\hline 3.03 & 1.64 & 38.4 & 182 & & & .229 & & $195^{\circ} \mathrm{C}$ & "1 \\
\hline 0.96 & 3.50 & 19.4 & 50.2 & & 1 & 115 & & $185^{\circ} \mathrm{C}$ & 11 \\
\hline 1.87 & 3.78 & 18.3 & 68 & & & 132 & & $190^{\circ} \mathrm{C}$ & 倚雨 $1.20 \mathrm{~g} /$ 本 \\
\hline 3.25 & 3.05 & 19.7 & (55) & & & 143 & $\cdot$ & $195^{\circ} \mathrm{C}$ & 荷重 $1.82 \mathrm{~g} /$ 本 \\
\hline
\end{tabular}

著であり，相賞に强度强き持にはその相異が僅少の樣である。比較のため乾熱延伸をも同一試料につ

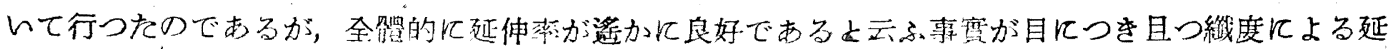

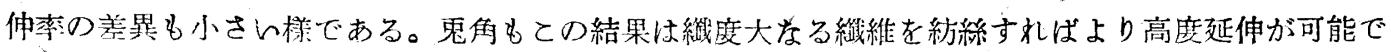

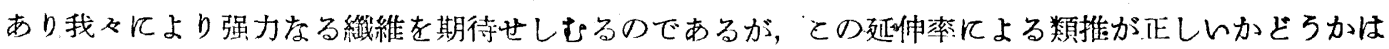
延伸率の墫加のみをもつて判定する事は早計の樣である。てれて關しては今後實驗を行ふ積りである。

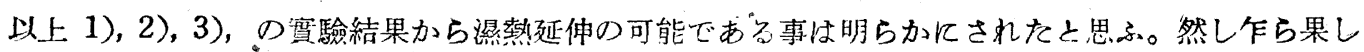
て乾熱延伸の場合之同樣延伂効果，郎ち延伸によつて强度が上昇するかどらかは不明であり，份第 3 表に見る如く乾熱延伸率が濕熱延伸率に比へて遥かに大である之云ふ事からも相當に筑問がある。郎 ち乾熱延伸之同じ延伸効果は娥期活來ないと考へられるのであるが，とと迄有效であるか，又全及効 果が無いか，次に之等延伸率之强伸度との關係を明らかにすへく實驗を行つた。

4) 濕熱延伸化依る强度變化

今迄の實驗は單䋐維を用ひて延伸を行つたのであるが强蚛度を測定する第には可成りの量が必要で

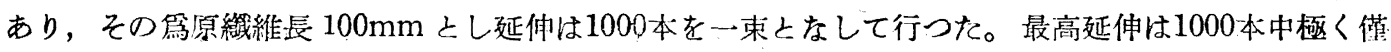

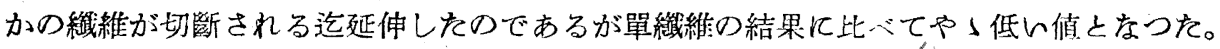

佾延伸後は緊張乾燥し，その鰮收縮しない樣注意して $200^{\circ} \mathrm{C}, 6$ 分間, 熱處理し, 第 $1 \mathrm{~A}$ ホルマリン 處理浴 ${ }^{3)}$ 中で $40^{\circ} \mathrm{C}, 1$ 間時處理， 水洗後風乾，恒溫恒缹室にて R. H. $65 \%, 20^{\circ} \mathrm{C}$ で强伸度を測定し た, 測定回數 50 本。

\section{a) 原纖維の强度 $3.32 \mathrm{~g} / \mathrm{d}$ の場合}

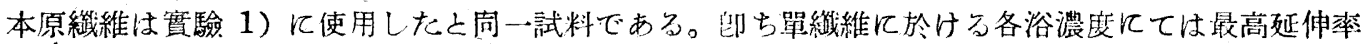

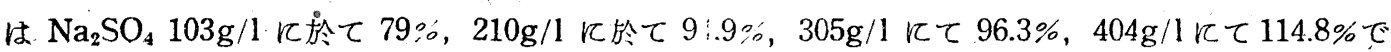
あるが次示す如くや〉多量に延侧を行ふ場合その最高延伸率は低下してるる。

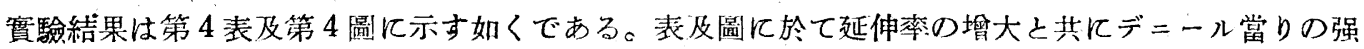
度は向上し，伸度は低下してるるのであつて，乙の事は乾熱延伸の場合て比へて相異は認められない

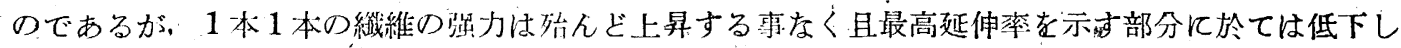
てるる㥞である。次に强度上昇の關係が浴濃度に影響されるや否や之云ふ問題である。てれも第 4 凅

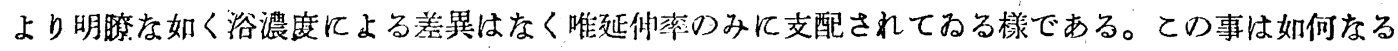
方法（浴浱度及浴溫度）でもよりよく延仰出來る方法を選べばよい事になるのであるが，何れの浴濃

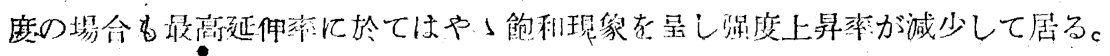




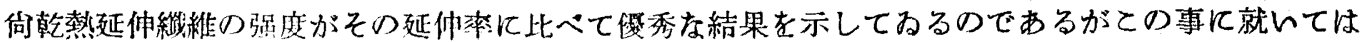
後述する。

第 4 各浴濃度に於ける延伸率と强伸度との關係

\begin{tabular}{|c|c|c|c|c|c|c|c|c|c|}
\hline 浴 & 沸 & 度 & \multirow{2}{*}{$\begin{array}{c}\text { 延伸侮度 } \\
\left({ }^{\circ} \mathrm{C}\right)\end{array}$} & \multirow{2}{*}{ 延伸率: } & \multirow{2}{*}{$\bar{\gamma}^{\prime}=-ル$. } & \multirow{2}{*}{$\begin{array}{l}\text { 乾 强 } \\
(\mathrm{g} / \mathrm{d})\end{array}$} & \multirow{2}{*}{$\begin{array}{l}\text { 乾 伸 } \\
(\%)\end{array}$} & \multirow{2}{*}{$\underset{(\mathrm{g})}{\text { 强 }}$} & \multirow{2}{*}{$\begin{array}{c}\text { 强度上昇率 } \\
(\%)\end{array}$} \\
\hline $\mathrm{Na}_{2} \mathrm{SO}_{4}(g$ & & $\mathrm{ZnSO}_{4}(g / 1)$ & & & & & & & \\
\hline & & . & - & 0 & 2.19 & 3.32 & 22.0 & 7.29 & 0 \\
\hline 96 & & 15 & 60 & $25(16.5)$ & 1.88 & 3.91 & 18.6 & 7.26 & 17.8 \\
\hline " & & $v$ & & $50(30)$ & 1.68 & 4.14 & 17.1 & 6.95 & 24.7 \\
\hline 201 & & 15 & 90 & $25(23)$ & 1.78 & 4.26 & 18.0 & 7.60 & 28.2 \\
\hline " & & " & " & $50(42)$ & 1.54 & 4.79 & 13.8 & 7.48 & 44.1 \\
\hline "I & & "I & "l & $72(59)$ & 1.38 & 4.96 & 14.5 & 6.84 & 49.2 \\
\hline 300 & & 17.5 & 90 & $25(22)$ & 1.80 & 3.97 & 18.5 & 7.15 & 19.6 \\
\hline " & & "I. & "I & $50(33)$ & 1.64 & 4.52 & 15.1 & 7.42 & ' 36.1 \\
\hline$"$ & & "I & " & $75(51)$ & 1.45 & 4.48 & 16.1 & 6.50 & 35.1 \\
\hline 385 & & 16 & 90 & $25(24)$ & 1.76 & 4.08 & 17.9 & 7.18 & 22.9 \\
\hline "I & & " & " & $50(42)$ & 1.54 & 4.42 & 15.4 & 6.80 & 33.1 \\
\hline " & & " & " & $75(53)$ & 1.43 & 5.22 & 12.1 & 7.47 & 57.1 \\
\hline " & & " & 11 & $82(59)$ & 1.38 & 5.27 & 11.9 & 7.27 & 58.8 \\
\hline$n$ & & " & " & $100(65)$ & 1.33 & 5.45 & -.11 .2 & 7.26 & 64.1 \\
\hline 乾熱延伸 & & & 190 & $80(89)$ & 1.16 & 5.96 & 10.8 & 6.92 & 79.8 \\
\hline
\end{tabular}

绕：表中（，內の数字は喵测デニールより計算した延伸率 $(\%)$

第 4 圆 各浴漶度に於け万延伸率と强度 (a)

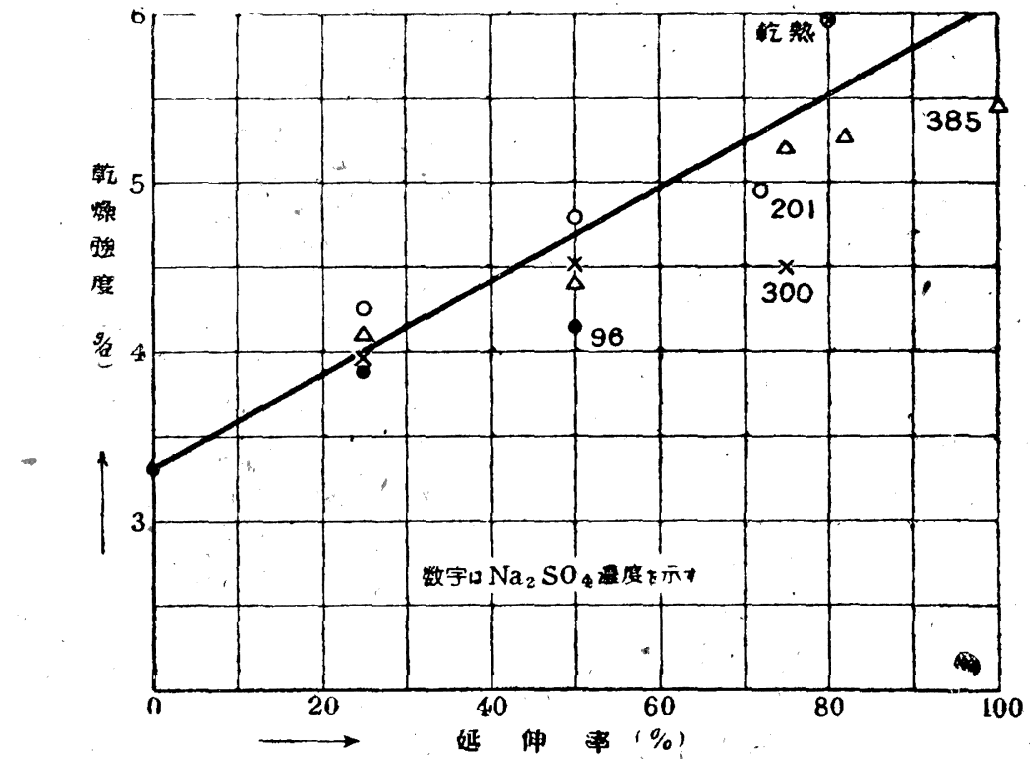

b）原絨維の强度 $4.01 \mathrm{~g} / 1$ の埸命

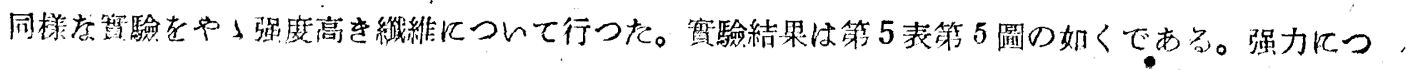




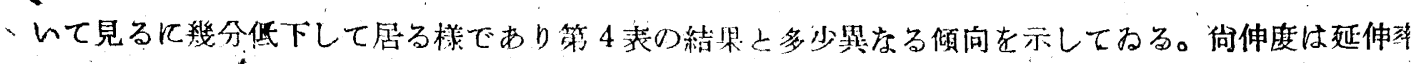

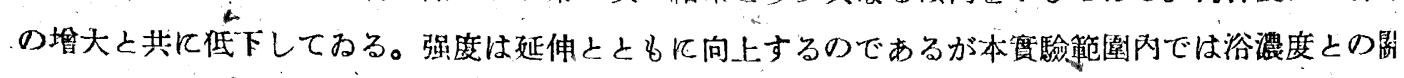
係が一見ある様に思はれるのであるがとの點を明膫に指摘する事は後述する如くや〉危險である。る 延伸率の最高の部分反於て飽和點の認められる事は a)の筫驗に於けると同㥞である。

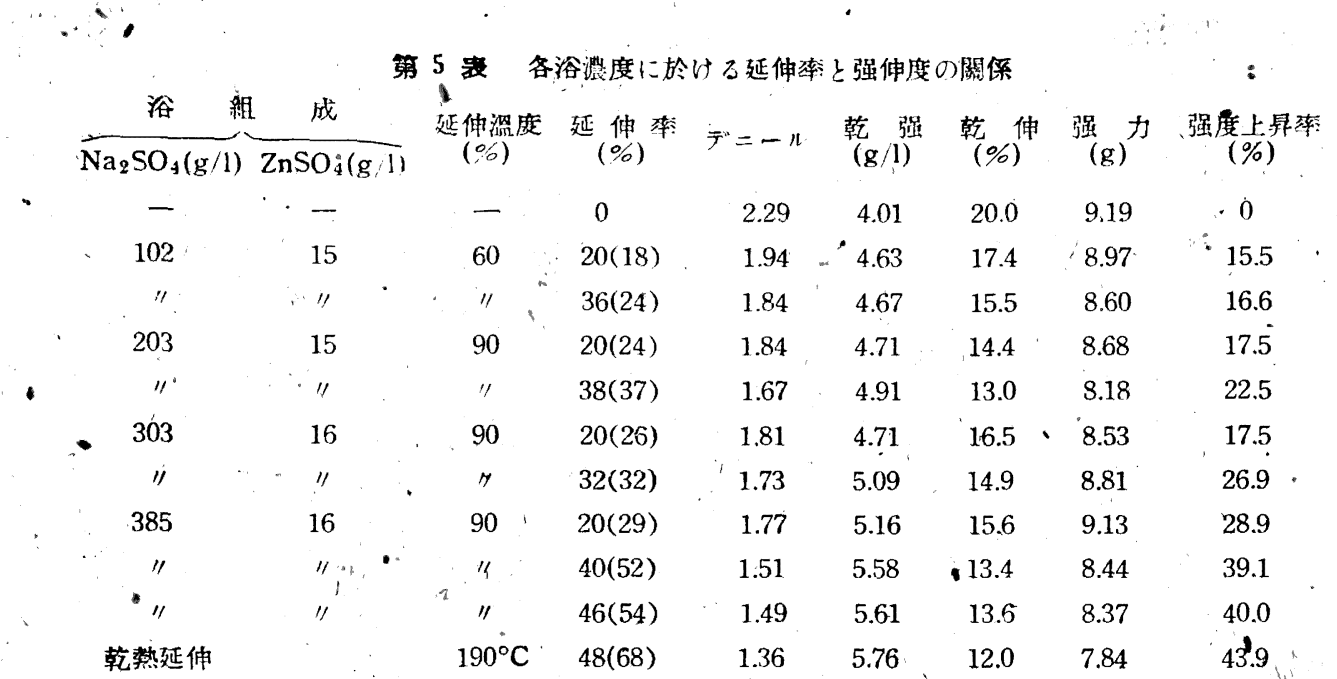

註:（）内の数字は赛测デニールよりの計算延伸率!

以上䨘驗 4）a）及 b) 亿於て延伸率之强仲度の 第 5 㖥 各浴湛度に於ける延伸率々强度 (b) 關係を究明したのであるが大體に於て延伸率の樰 加几從ひ强度は上算し伸度は減少するのである。 又强力は殆んど變化せず或ひ娆分低下の倾向を たどりての事は乾熱延伸の場合とや〉異なる結果”。 となった。

次に浴濃度之延伸効果之の關係であるが原䋊維 の强度大なる場合に於て性幾分浴濃度之延伸効果 が關係する如く觀察されるのであるが今暂測デニ 一ルょり延伸率を計算し，ての計算延伸率と强度。 の關係を見る之强度は計算延伸率?(これは冥の延 伸率之考へられるが）飞比例して上昇し，浴濃度

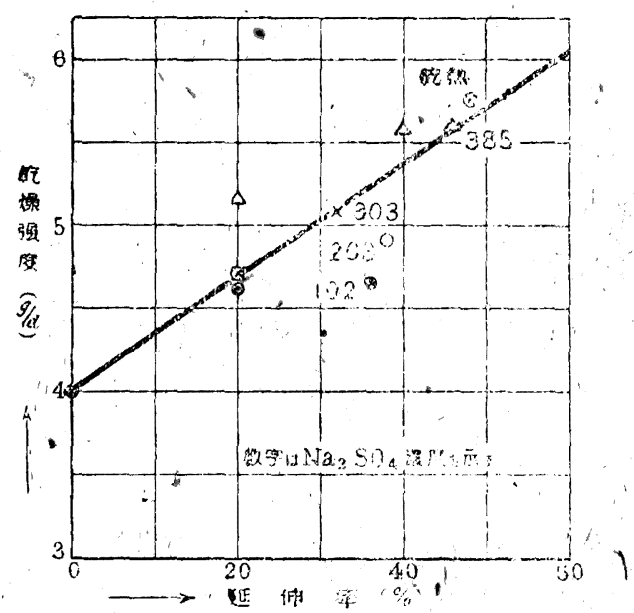

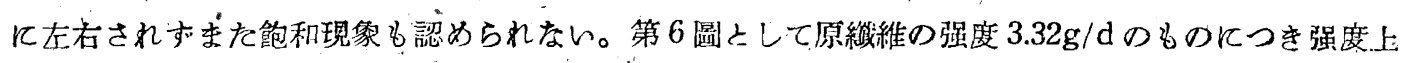
昇率とデニールよりの計算延伸率を示したが，延伸率と上昇率は數值的にも生ら相等しん。國は省略 するが原纖維强度 $4.01 \mathrm{~g} / \mathrm{d}$ の例飞於ては强度上昇率は延伸率より我分低的。

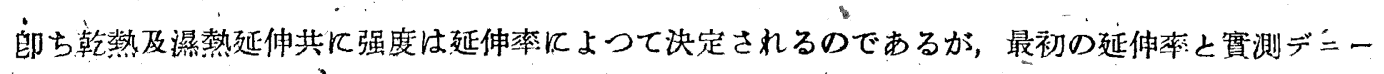

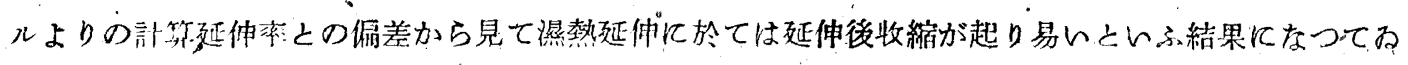
る。 


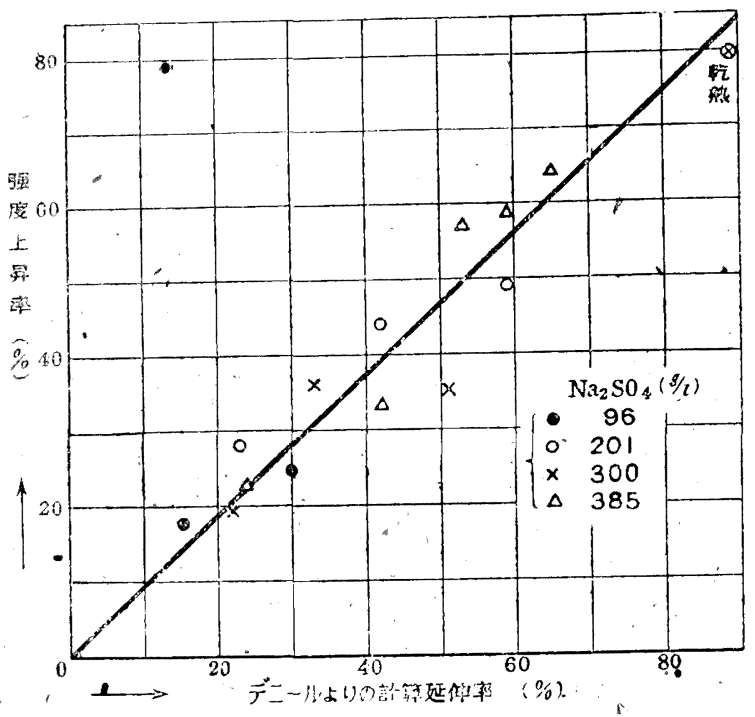

以上我々は芒矿浴を使用し P.V.A 纎維の签熱延伸に關し惯驗を行つたのであるがその結果を總括 すれば次の如くである。

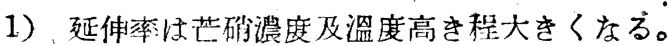

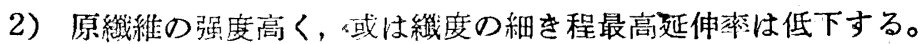

3）原㵶維の性質により幾分變化するが大體延伸後の强度はその延伸率に關係し，浴濃度には殆ん ど影響されず，且延伸効果は明瞭化認められる。

4）乾熱延伸に比べて最高延伸率低く，何延伸後收縮が起り易い。

最後に本貫驗に協力して戴いた上島，中西，林，时中君に感謝の意を表する次第である。

\section{文愿 。}

1）李，人晃：高分子化學，第 2 绎，第 4 號，P 1 (昭和20年).

2）撟：合成䋐維研究 2 (昭18)，78，214。

3）第 $1 \mathrm{~A}$ ホルマリン處理浴組成 ( $\mathrm{HCHO} 4 \%{ }^{\circ} \mathrm{H}_{2} \mathrm{SO}_{4} 20 \%, \mathrm{Na}_{2} \mathrm{SO}_{4} 25 \%$ ).

$$
\text { “高分子化學”バックナムバー }
$$

下記バックナムバー在庫あり。御希望者は选料を添へて本會大阪分室宛 御申出下さい。

第 3 號（1 圓)，第 4 號（1 圓)，第5.6號（2圓)，第 7 號(1 圓) 第 8.9 號（2圆），第10.11・12號（3圆），第 $13 \cdot 14 \cdot 15$ 號（3圆）。 